\title{
Indonesian Stratigraphic Nomenclature Revision: The first progress report
}

\author{
Herman Darman ${ }^{1 \#}$, Dwandari Ralanarko², Sugeng Sapto Suryono ${ }^{3}$, Hill Gendoet Hartono ${ }^{4}$, Dwiharso \\ Nugroho $^{5}$, Dewi Syafitri ${ }^{6}$, Abdurrokhim ${ }^{7}$
}

\author{
${ }^{1}$ INDOGEO Social Enterprise, currently with PETRONAS Carigali Sdn. Bhd \\ ${ }^{2}$ Pertamina OSES, Jakarta \\ ${ }^{3}$ Gadjah Mada University, Yogyakarta \\ ${ }^{4}$ Institut Teknologi Nasional, Yogyakarta \\ ${ }^{5}$ Institute of Technology, Bandung \\ ${ }^{6}$ Trisakti University, Jakarta \\ ${ }^{7}$ Padjajaran University, Bandung \\ "Corresponding author: herman_darman@yahoo.com \\ Present address: PETRONAS TWIN TOWER, Tower 2, Kuala Lumpur City Centre, 50088 Kuala Lumpur
}

\begin{abstract}
A team was formed by the Indonesian Association of Geologist (IAGI) in early 2021 to revisit the Indonesian Stratigraphic Nomenclature which was issued in 1996. After 25 years many experts find that the document needs to be updated. The team is a mix of geologists with both academic and industry background. Several representatives from the Geological Agency who are involved in the Stratigraphic Lexicon document were also invited in the discussion. The team meeting was set on a regular basis to evaluate the existing nomenclature and look on areas for improvement. In each meeting the team will discuss a certain section of the nomenclature document. A three-years work programme was set and reported on this article. In the first year the team will investigate areas for improvement, followed by revising necessary content in the second year. Implementation and promoting the nomenclature are planned for the third year.
\end{abstract}

This short communication aims to engage a wider community on the process in revisiting the Indonesian Stratigraphic Nomenclature. Several examples of discussion topics in the meetings were included in this article. Readers will see potential areas for improvement and the team are open for suggestions.

Keywords: Indonesian Stratigraphic Nomenclature, Stratigraphic Lexicon, volcanostratigraphy, lithostratigraphy, lithodemic

Copyright C2021. FOSI. All rights reserved.

Manuscript received July $28^{\text {th }}, 2021$, revised manuscript received August $10^{\text {th }}$,

2021, final acceptance August 12 ${ }^{\text {th }}, 2021$.

DOI: 10.518535/bsed.2021.47.2.39 


\section{INTRODUCTION}

In January 2021, the leadership of the Indonesian Association of Geologist (IAGI) formed a team to update the Indonesian Stratigraphic Nomenclature (Sandi Stratigrafi Indonesia or SSI for short). The letter was signed by IAGI former president, Sukmandaru Prihatmoko, and IAGI active president, Muhammad Burhannudinnur. The SSI team is composed of Herman Darman (INDOGEO Social Enterprise, currently with PETRONAS in Kuala Lumpur), Dwandari Ralanarko (Pertamina OSES, Jakarta), Sugeng Sapto Suryono (Gadjah Mada University, Yogyakarta), Hill Gendoet Hartono (Institut Teknologi Nasional Yogyakarta), Dwiharso Nugroho (Institute of Technology, Bandung), Dewi Syafitri (Trisakti University, Jakarta) and Abdurrokhim (Padjajaran University, Bandung). The main task of this team is to revisit the existing Indonesian Stratigraphic Nomenclature which was issued in 1996 (Martodjojo and Djuhaeni, 1996). After 25 years, there is an unofficial consensus among many
Indonesian geologists that some parts of the nomenclature need to be updated and improved. The new SSI needs to comply with the International Commission on Stratigraphy and to include recent development in geoscience. The improvement should make the guide clearer for application by geologists in Indonesia.

The 1996 document is a revised version of the 1973 SSI. Soejono Martodjojo was the team lead of the 1973 SSI, which was published by IAGI and he also led the 1996 revision team. The SSI document provides rules and guidance in giving names to specific rock units in Indonesia. It also useful for defining the boundary of a particular stratigraphic unit, provide the procedures in describing a new stratigraphic unit and help in ranking the hierarchy of the stratigraphic units. The rock grouping is based on similarity in their characteristics such as lithology and age. The lithological basis of grouping will generate lithostratigraphy and the age based of grouping is called chronostratigraphy. When the age

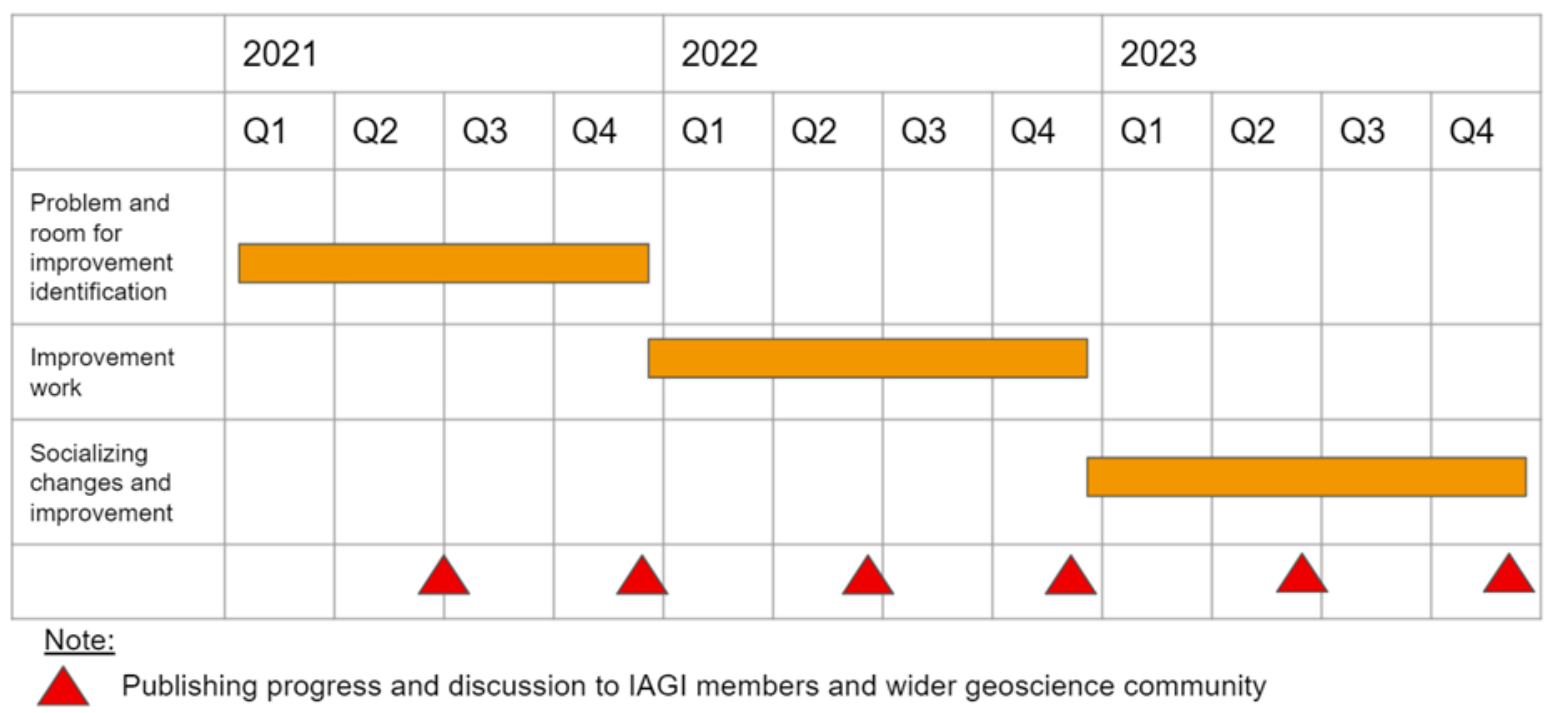

Figure 1. SSI team working plan, 2021-2023 
grouping is based on their fossil content, it is called biostratigraphy. There are many more methods developed to subdivide the rock units, including seismic stratigraphy, which is splitting the rock units based on their seismic character and, chemostratigraphy, which is based on chemical composition. In the 1996 edition, volcanostratigraphy, sequence stratigraphy and lithodemic have also been included.

The stratigraphic nomenclature provides guidance for Indonesian geoscientists to name the rock formation they observed in the field. The document will go hand-in-hand with the Stratigraphic Lexicon of Indonesia. The first lexicon was prepared by P. Marks and published in 1957 by the Indonesian Geological Agency (Pusat Djawatan Geologi; Marks, 1957). In 2003, the lexicon was updated by the Geological Agency
(Harahap et al., 2003) and is currently available online in the following link: https://geology.esdm.go.id/lexicon.

\section{WORK PROGRAMME}

The current SSI team has organized several monthly online meetings to review the 1996 SSI. Although the discussions are ongoing, it will probably be worth sharing the team's progress to the IAGI community. The team is expecting input, suggestions, and comments from a wider community, especially from IAGI members.

Starting in July 2021 the SSI team also invited experts from the Geological Agency who deal with updating the Stratigraphic Lexicon; represented by Asep Permana, Rina Zuraida and Ruly Setya. They have been involved in evaluating groups of rocks and assigning official names. In their activities they encountered several issues related to the SSI application, such as applying consistencies among researchers in giving formation names or rock groupings in general. For this task they require an updated SSI which should be in line with the guidance provided by International Commission on Stratigraphy. The SSI team may also provide suggestions
Figure 2. Stratigraphic table in SSI 1996. Red circles indicate areas for improvement which should follow the International Commission on Stratigraphy.

Adjust further to comply with International Commission on Stratigraphy 


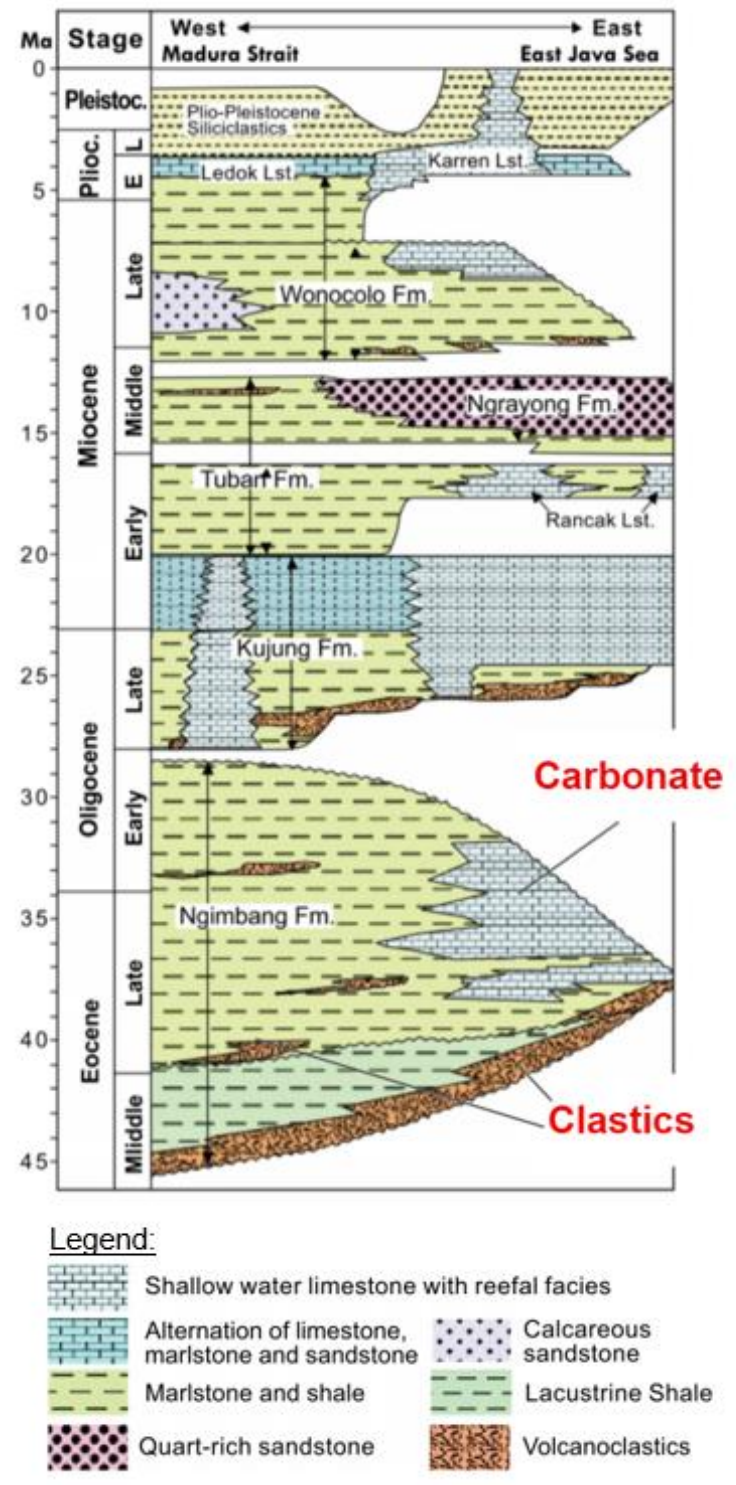

Figure 3. Generalized stratigraphy of the Cenozoic sediments in North East Java Basin (Syah et al., 2019, simplified from Mudjiono \& Pireno, 2001) using updated absolute ages (Ogg, Ogg and Gradstein, 2016). The following abbreviations are used: Fm., Formation; Lst., Limestone.

to Geological Agency in improving the lexicon.

The SSI team has designed a 3 years' work programme to achieve its target in revising the 1996 SSI as shown in Figure 1. In the first year, the team will identify problems and potential improvement on the 1996 SSI. The team will work on the improvement in the second year and provide cases where the improvement can be applied. The team will socialize the changes in the third year (Figure 1).

\section{DISCUSSIONS}

During the last 3 online meetings, the team has discussed four key problems and indicated room for improvement. Firstly, the current Indonesian stratigraphic nomenclature needs to comply with International Chronostratigraphic Chart which is published by the International Commission on Stratigraphy. Therefore, the stratigraphic scheme in the document needs to be adjusted accordingly. Secondly, most publications in Indonesia will refer to Epoch which is currently not included in the stratigraphic scheme. The subdivision of Mesozoic and Palaeozoic and absolute age of each chronostratigraphic boundary also needs to be refined and updated. The consistency between Indonesia and International Chronostratigraphic Chart is the main reason why the 1996 SSI document needs to be adjusted. Figure 2 shows the chronostratigraphic chart in the 1996 SSI and the red circles indicate the room for changes.

The Ngimbang Formation in East Java was discussed as an example of the second problem. This formation is of Eocene to Oligocene in age (Syah et al., 2019; Figure 3) and it contains both clastic and carbonate units, which are commonly called Ngimbang Clastic and Ngimbang Carbonate Formation, respectively. The naming of this formation is against the 


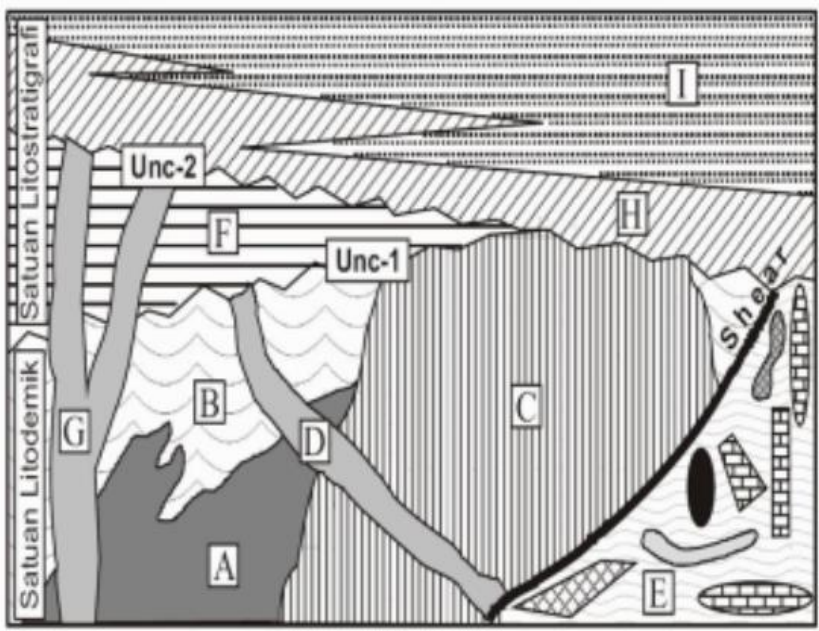

Figure 4. Lithodemic unit types in the 1996 SSI. The caption is written as follow: $A, B, C, D, E$ and $G$ are lithodemic units. $A B$ is suite one, $C D$ is suite two. $A B C D$ are grouped as supersuite. FHI are Lithostratigraphic units (Modified from NASC, 1993). The rock types need to be mentioned in the caption to give better understanding on how the lithodemic differentiate itself from lithostratigraphic unit.

lithostratigraphic principle because they have clearly different lithology. This formation is also known as a major source of hydrocarbon supply but has not been comprehensively assessed in terms of its role as a source rock and a reservoir (Pandito et al., 2017). Therefore it is important to name them properly according to the SSI guidance and the SSI Team also saw a requirement to change the lithostratigraphy of formations which contain petroleum system elements.

The third problem discussed is about the lithodemic which is discussed in Chapter II Articles 21-25 in the 1996 SSI. Lithodemic is defined as a group of rocks or bodies of rock whose character is not ruled by the Law of Superposition. A lithodemic unit is a three-dimensional body composed of one or more intrusive, highly deformed or highly metamorphosed rock types, distinguished and delimited on the basis of rock characteristics. This chapter has included a figure (Figure 4), which is adopted from the North American Stratigraphic Code (1983). More detailed explanation of the figure is required to further describe the rock types such as igneous and metamorphic. The igneous rock in the diagram should be defined further as volcanic complex, intrusion, and dike. The SSI may need to set a rule on how it will be defined in map legends as well.

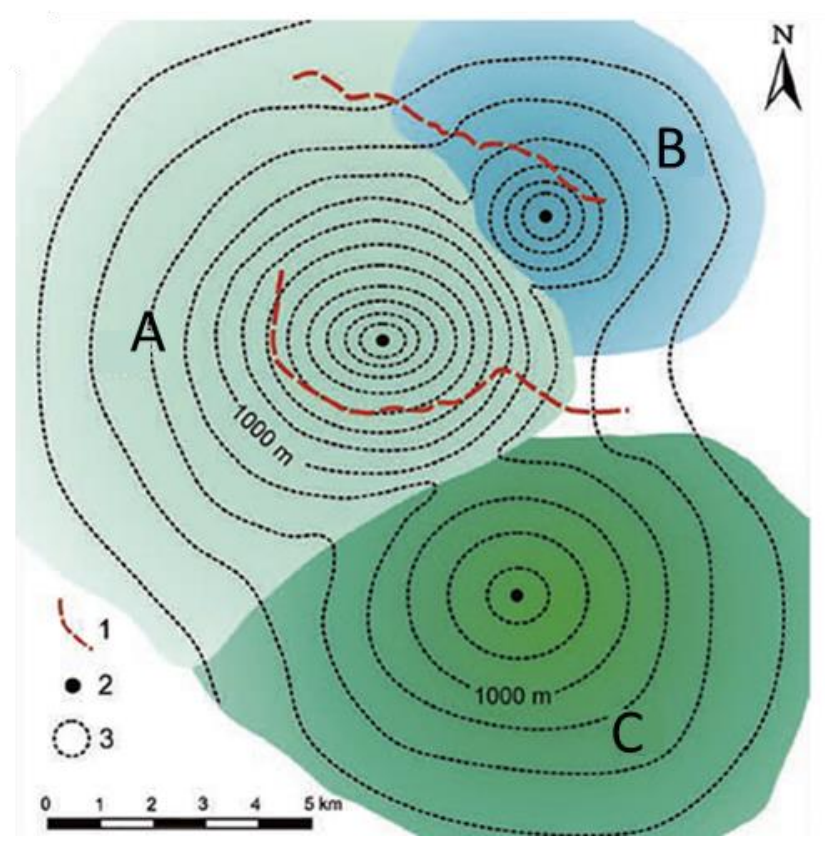

Figure 5. Distribution map of volcanostratigraphic units ( $A, B$ and $C$ ) which are derived from their sources, description and genetic. 1) Valley rim; 2) summit vent; 3) contour line (equidistance). This figure could be inserted in the coming SSI edition to explain more on the volcanostratigraphy. Adopted from Marti et al. (2018). 
Volcanostratigraphic nomenclatures are also discussed in Chapter III of 1996 SSI and this is another problem which needs refinement. The volcanostratigraphic units are systematically defined according to source, description and genetic. To give a better understanding on how to apply it on geological mapping or evaluation projects, at least a diagram needs to be included. Figure 5 shows an example of the map which is useful to explain that the volcanostratigraphic units are derived from their source.

\section{CLOSING REMARKS}

The SSI Team will continue with regular monthly meetings to discuss more on areas of improvement observed in the 1996 SSI. The examples discussed above shows where the team may work on to come up with an updated better SSI. The team is also expecting active participation from IAGI members and the wider geoscience community. Any suggestion or contribution is welcome to improve the existing 1996 SSI, by sending their comments and concerns to the correspondence author of this article

Engagement with a wider audience will be arranged through webinars organized by IAGI or its sections such as the Indonesian Sedimentological Forum (FOSI) yearly. In case there is an urgent topic to be discussed with the geoscience community, a special event can be arranged.

\section{REFERENCES}

Harahap, B. H., Bachri, S., Baharuddin, Suwarna, N., Panggabean, H. and Simandjuntak, T. O., 2003.
Stratigraphic Lexicon of Indonesia. Geological Research \& Development Centre, Bandung. https://geology.esdm.go.id/lexicon.

Marti, J., Grouppelli, G. and da Silveira, A. B., 2018. Volcanic stratigraphy: A review. Journal of Volcanology and Geothermal Research 357, 68-91.

Marks, P., 1957. Stratigraphic Lexicon of Indonesia, Volume 31 of Republik Indonesia. Kementerian Perekonomian, Pusat Djawatan Geologi, Publikasi keilmuan, Seri geologi

Martodjojo, S. and Djuhaeni, 1996. Sandi Stratigrafi Indonesia. Ikatan Ahli Geologi Indonesia

Mudjiono, R. and Pireno, G. E., 2001. Exploration of The North Madura Platform, Offshore East Java, Indonesia. Proceedings Indonesia Petroleum Association, 28th Annual Convention and Exhibition, Jakarta

NACSN (North American Commission of Stratigraphic Nomenclature), 1983. North American Stratigraphic Code. American Association of Petroleum Geologists Bulletin, 67

Ogg, J. G., Ogg, G. and Gradstein, F. M., 2016. A Concise Geologic Time Scale: 2016. Elsevier

Pandito, R. H., Haris, A., Zainal, R. M. and Riyanto, A., 2016. Hydrocarbon potential assessment of Ngimbang formation, Rihen field of Northeast Java Basin. Proceedings of the 2nd International Symposium on Current Progress in Mathematics and Sciences 2016. 
Soejono, M., 1973. Sandi Stratigrafi Indonesia. Komisi Sandi Stratigrafi, Ikatan Ahli Geologi Indonesia, Jakarta.

Syah, M. H. F., Kano, A., Iizuka, T. and Kakizaki, Y., 2019. Depositional and diagenetic history of limestones and dolostones of the Oligo-Miocene Kujung Formation in the Northeast Java Basin, Indonesia. Island Arc, 28(6). 